\title{
An Evaluation of Primary School Year 6 (KSSR) English Textbook
}

\author{
Muska Momand, Ambiga Sugunabalan, Said Ahmed Mustafa Ibrahim, Sandaran SC
}

\begin{abstract}
This study investigates the effectiveness of Malaysian Primary School Year 6 (KSSR) English textbook to determine the extent to which the textbook conforms to the universal characteristics of ESL/EFL textbooks. A modified version of Alamri's (2008) English as Foreign Language (EFL) textbook evaluation checklist developed by Akef and Moosavi (2014) was distributed along with the textbook to 12 TESL postgraduate students and 18 primary school English Language teachers currently studying at University Technology Malaysia (UTM) for evaluation. The data collected from this study was analysed using descriptive statistical technique which is a quantitative method. The findings highlight some of the weaknesses of the textbook in compliance to the universal characteristics of ELT textbooks. These include lack of supplementary materials and teachers' dissatisfaction towards language contents and language skills elements. The findings from this study can provide significant feedback for teachers, textbook designers, curriculum developers and policy makers to place more emphasis on textbook evaluation when developing textbooks.
\end{abstract}

Keywords: English textbook, evaluation, Primary school, Year $6($ KSSR)

\section{INTRODUCTION}

The quality of teaching and learning English can be determined to a great extent by the quality of the teaching materials used, especially the textbook [1]. In a similar vein, [2] highlighted that textbooks provide an invaluable resource for both learners and teachers and play a vital role in language teaching.

Therefore, teaching materials in general and textbooks in particular must be evaluated to ensure high quality of teaching of the English Language. In Malaysian public schools, English is taught as a second language. And in recent years, evaluation of English Language textbooks has been given more attention. Example of studies include [3] and [4] investigation the effectiveness of the English language textbooks used in secondary schools in Malaysia.

Their findings have shown that the textbooks needed improvement, and have recommended further evaluation of the textbooks by using other instruments and larger samples. Others have examined the content of Malaysian secondary school English textbooks and reported that exercises on the teaching if articles for example, lack variety [5].Thus, many

Revised Version Manuscript Received on April 19, 2019.

Muska Momand, Balkh University, Kabul, Afghanistan.

Ambiga Sugunabalan, Faculty of Social Sciences, Universiti Teknologi Malaysia, Johor, Malaysia

Said Ahmed Mustafa Ibrahim Faculty of Social Sciences, Universiti Teknologi Malaysia, Alexandria, Egypt.

Sandaran, SC Language Academy, Universiti Teknologi Malaysia, 81310, Johor Bahru, Johor, Malaysia studies have focused on evaluation of Malaysian EL textbooks. Despite the body of literature on textbook evaluation in ELT, there is still a need to evaluate Malaysian primary school textbooks because of the many changes to the syllabus and textbooks in recent years. The current study aims to investigate how far the Malaysian Primary 6 (KSSR) English textbook is compliant to the universal characteristics of ESL/EFL textbooks in general.

Investigating the weaknesses and strengths of the English language textbooks and making sure that they are in line with the current curriculum trends in ELT and recent pedagogical principles might contribute to the effectiveness of the current textbook and hence lead to high quality teaching of the English language at the primary school level in Malaysia. Therefore, the current study aims to answer the following research questions:

i. What are the weaknesses and strengths of Primary School Year 6 (KSSR) English textbook in Malaysian schools?

ii. To what extent does the ESL textbook used for Year 6 (KSSR) in Malaysian primary schools conform to the universal characteristics of ESL/EFL textbooks?

\section{LITERATURE REVIEW}

Textbooks seem of paramount importance for teaching. [6] Addressed textbooks as a fully specified and pre-constructed framework that provides consistency in the classroom environment to serve the interests of accountability. [7] Discussed textbooks as a self-directed learning tool, an effective source of material, a reference source for students, a syllabus, source of ideas and activities, a support for less experienced teachers and very much valuable in teaching and learning process.

In English language learning, textbooks are considered as published books designed to contribute to language learners in improving their linguistic and communicative abilities [8]. Textbooks are also supportive teaching materials in addition to being a learning tool [9]. [2] Highlighted that textbooks provide a valuable resource for both learners and teachers and play a vital role in language teaching, but most of the current ELT textbooks are developed for commercial purposes. They are not developed based on principles of language learning that most educators and linguists recommend. [10] The current textbooks are more biased toward perceived rather than the actual needs of learners. According to him most of 
the textbooks fail because instead of focusing on students' needs, the writers rely on insights and develop materials they think would work best for their intended users.

In order to ensure the efficiency of textbooks, it is essential to conduct an evaluation of EFL/ESL textbooks to facilitate the fulfilment of teaching objectives and, on the other hand, be economically sustainable for both teachers and students. Indeed, both teaching and learning would be negatively affected by the wrong choice of a textbook. [11] Stated that the importance of conducting textbook evaluation is either to choose textbooks for a newly started language program, or to find out the strength and weaknesses of the books and then make a decision whether to maintain, improve, or substitute them.

Knowing about the significance of textbook evaluation, it is necessary to find out the ways of evaluating and to follow the criteria in the evaluation process. [8] Stated that we cannot only bound ourselves to checklists or scoring systems because in all different situations, one set of criteria is not appropriate. Evaluation sheets include a list of factors such as rationale, availability, layout, and so on, and these factors are measured based on Likert scale such as poor, fair, good and excellent. Checklists can be both systematic and time and cost effective. Besides, understanding, replicating and comparing of the results are quite easy through using of checklist [12]. In addition, we can update them based on each learning situation requirement.

Many studies have been done around the world that evaluated school textbooks with different instruments from different points of view. The findings of a study [13] in which three Grade 4 textbooks were evaluated showed that students acknowledged the textbooks appealing design and well-constructed illustrations. The books contained attractive and well-produced vocabulary, explicit and comprehensible instruction with authentic example, topics, content and activities. The four language skills development was promoted with balance in all three books.

A similar study by [14] evaluated three textbooks of Grade 4 for primary schools prescribed by the National Education Ministry of Turkey. This study evaluated various aspects of the textbook. The respondents who were both teachers and students responded to a textbook evaluation scheme of 37 items similar to a questionnaire to know their perceptions regarding different aspects of the textbook. The participants were also interviewed to get their in-depth perceptions into the use of textbooks. Findings indicated the appropriateness of the three textbooks for young learners, but suggestions were made in terms of future revision and design of the textbooks.

Similarly [7] claimed that the right choice of textbooks selection has become more difficult because of the increased number of textbooks in the market. He further argued that selection of the right textbook can have a considerable impact on the learning and teaching process. Therefore, the quality of textbooks is undoubtedly imperative as it can affect the success and failure of the ESL/EFL course [4]. A research conducted on the significance of knowing the selection and process of textbook materials by [15] discussed that textbook materials should be selected based on the local context that fulfil the needs of all learners.
In the Malaysian context, a study by [16] assessed English textbooks utilized for Years 1 to 6 and Forms 1 to 5 in relation to general attributes and content of teaching-learning. Teachers of Year 1 to 6 reported that the textbooks were greatly effective. Concurrently teachers of Form 1 to 5 responded that the current textbooks were fairly effective for students both in terms of the teaching-learning content and attributes.

Another study by [17] discussed a corpus-based evaluation of English prepositions presented in three lower secondary English textbooks in Malaysia. The finding revealed the difference between the frequency order of many prepositions in corpus and BNC (British National Corpus). The findings can direct teachers towards choosing the best supplementary materials with the textbooks that will provide the learners with the opportunity to be exposed to grammar items which are not presented appropriately in the textbooks. Furthermore, in an evaluation of $10 \mathrm{ESL} / \mathrm{EFL}$ textbooks by [18], they outlined physical make-up, content presentation, approach, and administration concerns as the universal characteristics of standard textbooks that should be considered in selecting a textbook for students. They added that each set of these standards consist a numbers of categories that would not be present in every textbook.

Drawing on the previous studies such as those mentioned above, the current study focused on perceptions and reflections regarding the effectiveness of the textbooks for primary schools in Malaysia. While there have been many studies conducted on Malaysian ESL textbooks, there is still a need to evaluate the effectiveness of Year 6 (KSSR) textbook. Thus, this study fills the gap in literature by examining the effectiveness of Year 6 (KSSR) English textbook used in Malaysian primary schools to consider how it conforms to the and universal characteristics of ESL/EFL textbooks. The findings would contribute to a better understanding of the effectiveness of the current textbook for primary schools in Malaysia.

\section{METHOD}

The research method employed in this study is a quantitative design using a checklist type questionnaire (Appendix A). This small scale study was conducted among 12 TESL postgraduate students and 18 English Language teachers in primary schools around Johor Bahru, Johor. All 30 participants of this study were enrolled in a TESL postgraduate course at Universiti Teknologi Malaysia and have minimum of 3 years of English teaching experience in primary, secondary and tertiary educational institutions.

As for the instrument used, respectively the checklist used is a; modified version of English as Foreign Language (EFL) textbook evaluation, developed by [19]. The researchers adopted this checklist due to the elements and items in the checklist which met the objectives and purpose of the current study. The checklist consists of two parts; Section A which is 
on the demographic information of the participants and Section B is on the characteristics of the textbook. Section B includes 40 items which are grouped under eight categories: General Appearance; Design and Illustration; Accompanying Materials; Topic Contents; Language Contents; Social and Cultural Contexts; Language Skills; Exercises and Activities. The weighting system is based on Likert Scale ranging from one up to four; strongly disagree, disagree, agree, strongly agree.

The research procedure began by distributing the checklist to the participants along with the Year 6 (KSSR) English textbook which was to be evaluated. Following that, the data collected from this study was analyzed using a quantitative method which is descriptive statistical technique by calculating the percentages for each item in the checklist in terms of the participant's agreement and disagreement levels.

\section{A. Materials}

For the purpose of this study, the Year 6 (KSSR) English textbook used to teach English Language in primary schools in Malaysia is the focus. The study is conducted to evaluate the effectiveness of the textbook in terms of its strengths and weaknesses.

\section{RESULTS AND DISCUSSION}

The textbook evaluation checklists were analyzed through calculating the percentage of agreement and disagreement for each main item and the findings are presented in the sections that follow. This is a descriptive analysis of the checklist where the researchers interpret the results in terms of the strengths and weaknesses of the primary Year 6 (KSSR) English textbook.

The degree of agreement and disagreement in percentage calculation for each of the main item in the checklist will reveal the teachers' preferences and views of how each item is important, necessary, and adequate or needs improvement. Strengths of textbook refer to important, necessary and adequate aspects; while weaknesses of textbook refer to aspects which need improvement or modification. Table 1 below displays the summary of data analyzed from the checklist evaluation in percentage calculation for every main category of items.

Table 1: Summary of data in percentage form

\begin{tabular}{|c|c|c|c|c|}
\hline \multirow{2}{*}{$\begin{array}{l}\text { Main Item in } \\
\text { checklist }\end{array}$} & \multicolumn{4}{|c|}{ Percentage $(\%)$} \\
\hline & $\begin{array}{l}\text { Strongly } \\
\text { Disagree }\end{array}$ & Disagree & Agree & $\begin{array}{l}\text { Strongly } \\
\text { Agree }\end{array}$ \\
\hline $\begin{array}{l}\text { A- General } \\
\text { Appearance }\end{array}$ & 9 & 17 & 31 & 43 \\
\hline $\begin{array}{l}\text { B- Design and } \\
\text { Illustration }\end{array}$ & 7 & 23 & 54 & 16 \\
\hline
\end{tabular}

\begin{tabular}{|l|lccc|}
$\begin{array}{l}\text { C- Accompanying } \\
\text { Materials }\end{array}$ & 100 & 0 & 0 & 0 \\
$\begin{array}{l}\text { D- Topic } \\
\text { Contents }\end{array}$ & 8 & 13 & 43 & 36 \\
$\begin{array}{l}\text { E- Language } \\
\text { Contents }\end{array}$ & 13 & 43 & 14 & 30 \\
$\begin{array}{l}\text { F- Social and } \\
\begin{array}{l}\text { Cultural } \\
\text { Contexts }\end{array}\end{array}$ & 0 & 10 & 23 & 67 \\
$\begin{array}{l}\text { G- Language } \\
\text { Skills }\end{array}$ & 13 & 56 & 16 & 15 \\
$\begin{array}{l}\text { H- Activities and } \\
\text { Exercises }\end{array}$ & 7 & 17 & 23 & 53 \\
\hline
\end{tabular}

\section{V.DISCUSSION OF THE RESULT}

\section{A. General Appearance}

Based on Table 1, percentage for agreement is at $74 \%$ with disagreement at $26 \%$ for Item 1 (General Appearance). This implies that the overall layout of the textbook is adequate, considering the paper quality and general physical attributes. This book is given a suitable title along with the content in the book which had been ordered from easy to more difficult levels; hence is appropriate for the target learners. The book has a complete table of contents as well. The good printing not only makes the book look attractive but also could motivate learners to read. This is crucial for encouraging individual learning in and outside the classroom. Also it is mentioned that the paper quality and the books' binding is strong, thus the durability aspect is high along with interesting physical appearance. Therefore, the general appearance element is considered as one of the strengths of the KSSR English Year 6 textbook. This is parallel to the suggestions given by [8] and [16], about the importance of layout and general quality of the textbooks in ensuring durability and effective use of those books.

\section{B. Design and Illustration}

Table 1 above shows the percentage for agreement is at 70 $\%$ while disagreement is at $30 \%$ for Item 2 (Design and Illustration). Apart from the glossary section subheading, all the other subheadings received high rank of agreement. It is found that the layout and design overall is appropriate and clear with varied and attractive illustrations in each unit of the textbook. As mentioned by [12] the design and illustrations are in crucial in sustaining the attention and interest of students using the books. The illustrations used are functional and help teachers to facilitate students' learning while also stimulating the learners to be creative. Generally, this item has received high rank of agreement, hence the design and illustration element is considered as one of the strengths of the KSSR English Year 6 textbook. 


\section{C.Accompanying Materials}

Based on Table 1, percentage for agreement is at $0 \%$ while disagreement at $100 \%$ for Item 3(Accompanying and Materials). Since there are no extra workbook to supplement or teachers' guide that accompany this textbook, this item has received $100 \%$ of total disagreement. Thus, it clearly becomes a significant weakness of KSSR English Year 6 textbook.

\section{D.Topic Contents}

Table 1 displays percentage for agreement is at $79 \%$ while disagreement at $21 \%$ for Item 4 (Topic Contents). This implies the topics included in the textbook are appropriate to the learners' level and life contexts. The topics are indeed interesting and motivating to learners while also encouraging them to express their own views critically. The content is realistic and matches largely to the lives of learners; while avoiding potentially embarrassing or sensitive topics. [18] Stated in their study that topics need to be carefully selected and elaborated to serve this purpose. Therefore, since this item has received high rank of agreement, it can be concluded that the topic contents element is considered as one of the strengths of KSSR English Year 6 textbook.

As shown in Table 1, percentage for agreement is at $44 \%$ while disagreement at $56 \%$ for Item 5 (Language Contents). There is a immense disagreement on this aspect about the language contents and whether they suit the language needs of learners. Grammar rules are not presented with clear and simple explanations, and the textbook has insufficient materials for training of pronunciation because it is not built through different types of activities such as listening, speaking, reading and writing. There is a lack of materials to teach both vocabulary and pronunciation. In addition, the materials for teaching grammar, vocabulary and skills and content intended need to take into account learners' needs mainly apart from other factors such as learning styles and pedagogical approach [18] [17]. So, language content is perceived as one of the weaknesses of KSSR English Year 6 textbook.

\section{F. Social and Cultural Contexts}

Based on Table 1 above, the percentage for agreement is at $90 \%$ and disagreement at 10\% for Item 6 (Social and Cultural Contexts). The social and cultural contexts are comprehensible and relatable to the learners where the textbook contains positive view of ethnic origins, occupations, age groups, social groups and disability. [17] learners and encourage them to use the material presented more effectively other than being actively engaged in the lessons and class activities. Similarly, [15] discussed that ELT textbook materials should be selected based on local context that fulfil the needs of any learner. Overall, Item 6 on social and cultural context of the textbook clearly is implied as strength of KSSR English Year 6 textbook since the percentage of agreement is high.

\section{E. Language Contents} pronunciation are graded inappropriately The organization of Mentioned that socio-cultural elements will be significant to

\section{G.Language Skills}

Table 1 above shows the percentage for agreement is at $31 \%$ while disagreement at $69 \%$ for Item 7 (Language Skills). This $69 \%$ of disagreement implies that the four skills of listening, speaking, reading and writing are inadequately covered throughout the book. Also materials for integrated skills work is lacking in the units. Reading skill is well organized into varied and interesting reading text which can engage learners cognitively and effectively. However, the listening materials of recording with authentic pronunciations together with background information, questions and activities for learners to practice have not been included. Similarly, there is insufficient material for spoken English such as role-plays and dialogues. The textbook lacks in the communicative aspect of language learning. As for writing activities, they are suitable in terms of length but lacking in degree of accuracy and amount of guidance. Language skills need to be organized efficiently according to the stages of learning and to individual learner requirements [17]. Clearly, the high percentage of disagreement for Language Skills implies as one of the weaknesses of the KSSR English Year 6 textbook.

\section{H.Activities and Exercises}

Based on Table 1 above, the percentage for agreement is at $76 \%$ while disagreement at $24 \%$ for Item 8 (Activities and Exercises). This percentage calculation shows that all the activities and exercises in the textbook are appropriate and matches the content well. Exercises have a clear direction, and provide meaningful and mechanical exercises and activities to practice language items and skills. There are appropriate numbers of exercises in the textbook with regards to correct use of language. [15] Also discussed those textbooks' materials that provide efficient exercises benefit both the teachers and learners highly. Therefore, although the textbook lacks in providing communicative exercises to carry out real life tasks, the exercises and activities element is perceived as one of the strengths of the KSSR English Year 6 textbook.

In answering Research Question 2 of the study, i.e. to what extent does the Primary 6 (KSSR) textbook conform to the universal characteristics of the ESL/EFL textbooks, the findings show 63 percent satisfaction of the teachers which means the textbook does in general conform to the universal characteristics of ESL/ EFL textbooks. However the findings also show that some of the weaknesses need to be looked into for further improvements.

\section{CONCLUSION}

The Year 6 KSSR English textbook evaluated in this study shows both strengths and weaknesses. In general, we can say that the respondents agreed that the textbook does conform to the universal characteristics of the ESL/EFL textbook. Some of the strengths of the textbook include the physical quality in terms of paper quality, binding and colorful printing. The 
content presented in the textbook is also coherent to the level of the learners and their different cultures have been represented very clearly through illustrations and content.

However, some weaknesses include the lack of accompanying material such as teachers guide or students' activity book, on top of the missing glossary section in the textbook. Furthermore, the English teachers also showed dissatisfaction towards the language content and language skills elements. Hence, as a recommendation it would be beneficial for teachers to adapt the existing materials in the textbook for those two aspects, particularly modifying the vocabulary, grammar and pronunciation presentation and practice stages, and add to provide accompanying materials and complete glossary in order to improve the textbook further.

In undertaking this study, we would like to add some suggestions, that textbook developers could include more universal characteristics that are tailored and adapted to the needs of learners into their ESL/EFL textbooks, based on a criteria list (checklist) which is commonly agreed upon. This is important since some textbooks may seem adequate on the surface level but, might actually lack in certain aspects when looked at and evaluated critically. This needs careful inspection by the language professionals before the textbooks are sent out for use in schools or other language institutions.

Therefore, it is significant for teachers, textbook designers, curriculum developers and policy makers to place more emphasis on textbook evaluation before finalizing the end product. They need to see the appropriateness of the contents included and to consider if the materials how would it cater to the varying needs of learners. It is crucial to strive to creating textbooks that match greatly to the needs and background of learners.

Therefore, it is significant for teachers, textbook designers, curriculum developers and policy makers to place more emphasis on textbook evaluation before finalizing the end product. They need to see the appropriateness of the contents included and to consider if the materials meet the varying needs learners. It is crucial to strive to create textbooks that match the needs and background of learners.

\section{APPENDIX A}

\section{TEXTBOOK EVALUATION TOOL}

The purpose of this checklist is to collect information on English teachers' views on strengths and weaknesses of Year 6 KSSR English Textbooks used in primary schools. It would be very much appreciated if you could spend a few minutes to read each statement given and circle the responses that you agree with the most, there is no right or wrong answers. All your responses will be kept confidential and strictly used for research purposes solely. Thank you very much for participating in the survey.

Section A: Personal Information

Name :

Age:

1. Are you an English teacher?

Yes .... No........

2. What is your highest qualification? :
a) $\mathrm{PhD}$
b) M Ed.
c) B Ed.

English Teaching Experience:
a. Less than one year
b. 1-2 years
c. 3-5 years

d. 5-10 years

e. 11-15 years

f. 16-20 years

g. More than 20 years

Section B: Please read the statements below carefully and put a tick $(\sqrt{ })$ next to the item which best reflects your view on the Year 6 KSSR English Textbook

\begin{tabular}{|l|l|l|l|l|l|}
\hline No & Item & Strongly Disagree & Disagree & Agree & $\begin{array}{l}\text { Strongly } \\
\text { Agree }\end{array}$ \\
\hline 1 & A-General Appearance & & & \\
\hline 2 & $\begin{array}{l}\text { The font type and size used in the series are appropriate } \\
\text { for the learners. }\end{array}$ & & & & \\
\hline 3 & $\begin{array}{l}\text { Every lesson is given an appropriate } \\
\text { title. }\end{array}$ & & & & \\
\hline 4 & The layout and design is appropriate and clear. & & & & \\
\hline
\end{tabular}




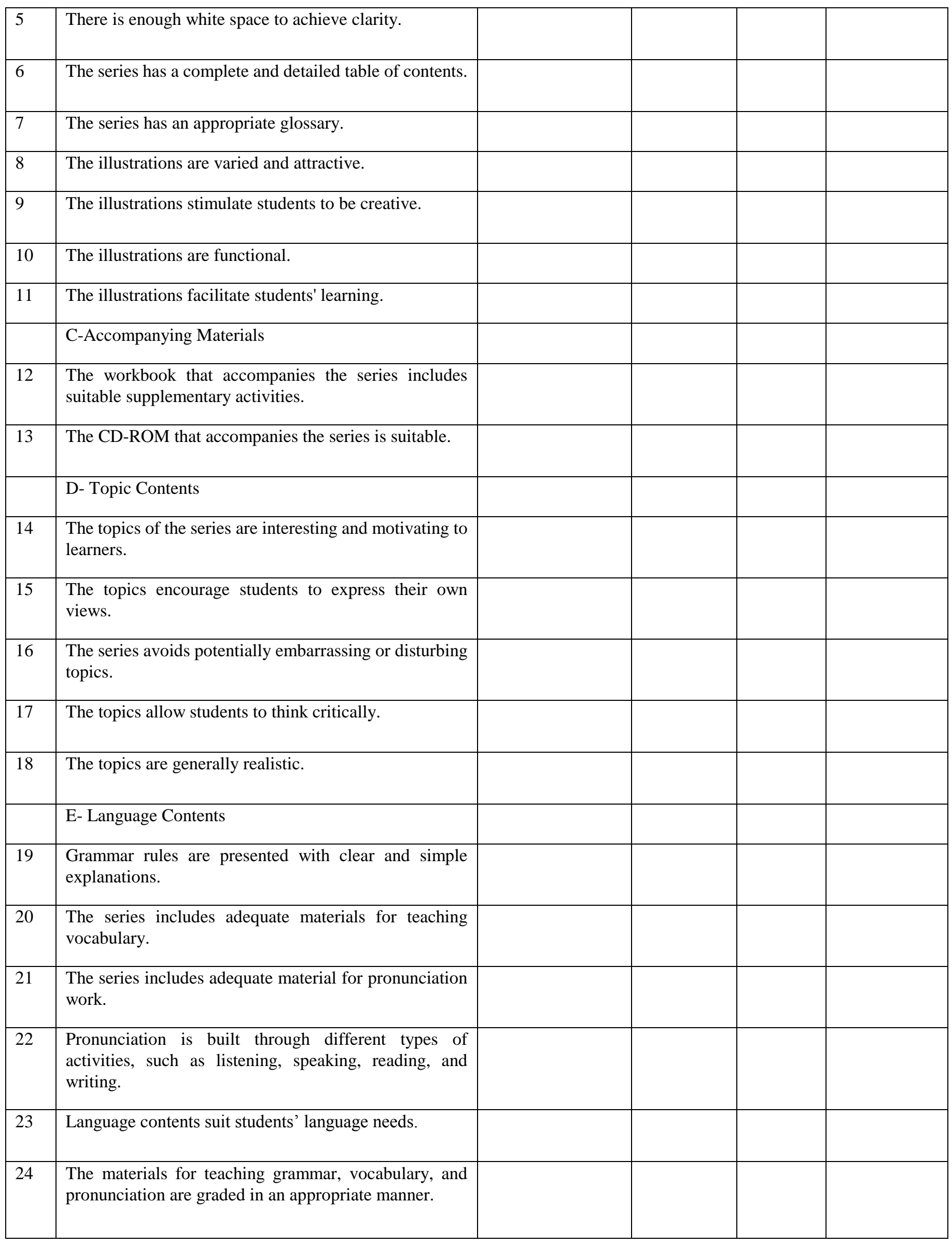




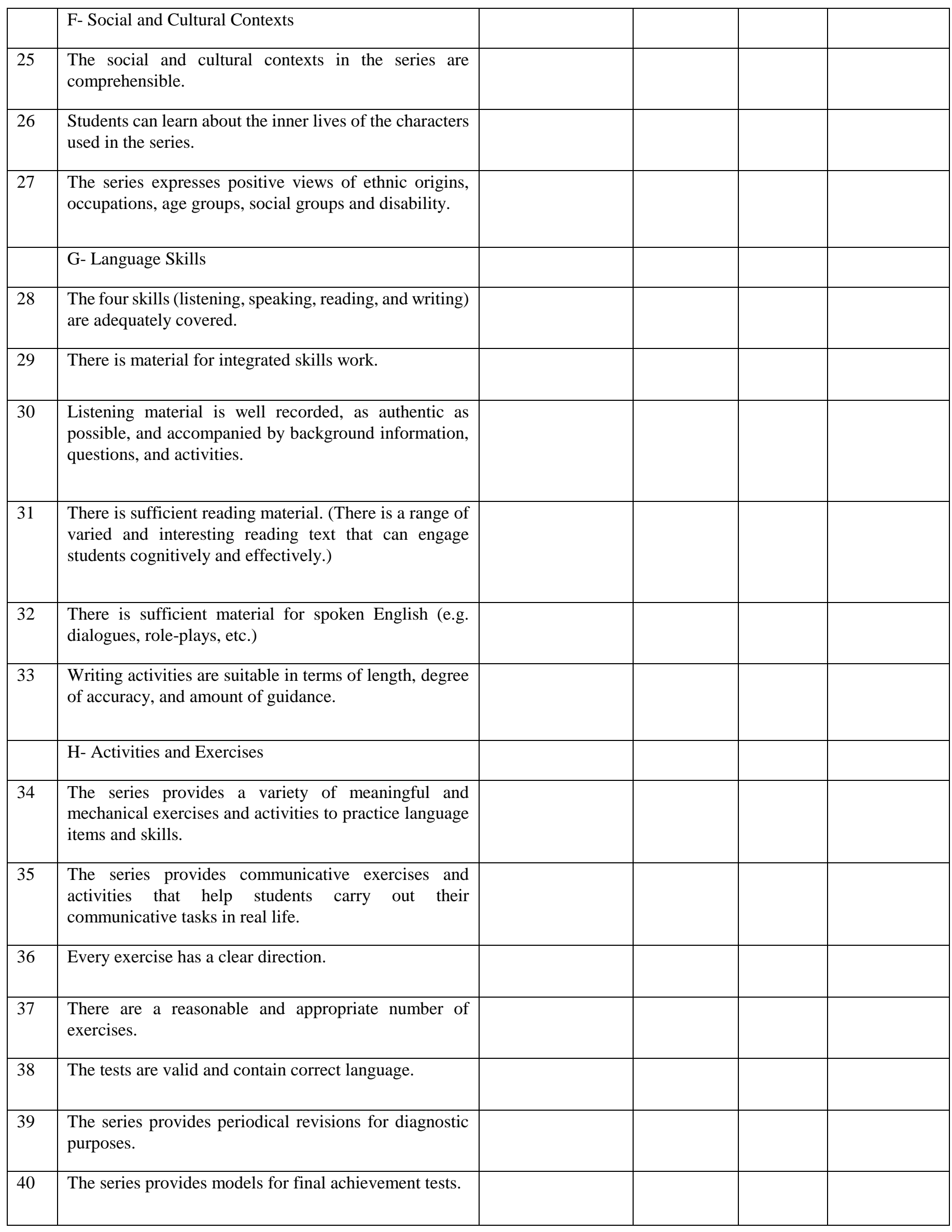

\section{ACKNOWLEDGMENT}

In conducting this research project, we were in contact with many people, especially language practitioners and teachers. They have contributed towards our understanding of the issue 
researched. In particular, we wish to express our sincere appreciation to this project supervisor, Dr. Shanti. We are very thankful for her guidance, advices and motivation in completing this research. Our sincere appreciation is also extended to all our fellow postgraduate students who have provided assistance at various occasions with their beneficial views and advices.

\section{REFERENCES}

1. Mukundan, J. (2010). Evaluation of English language textbooks: Some important issues for consideration. Journal of NELTA, 12(1), 80-84.

2. Çakit, I. (2006). Evaluation of the EFL textbook" New Bridge to Success 3" from the perspectives of students and teachers. Unpublished MA thesis, Middle East Technical University, Ankara, Turkey.

3. Ghazali, M. (2008). A Reflection of the Revised Syllabus Translated in Textbooks. Journal on International Management Studies, February, 162-169.

4. Mukundan, J. (2003). Readings on ELT Material. Kuala Lumpur: Universiti Putra Malaysia Press

5. Mukundan, J., \& Nimehchisalem, V., Hajimohammadi, R. (2011). Developing an English Language Textbook

6. Prabhu, N. S. (1987). Second language pedagogy (Vol. 20). Oxford: Oxford University Press.

7. Cunningsworth, A. (1995). Evaluating and selecting EFL teaching materials. Heinemann Educational.

8. Sheldon, L. E. (1988). Evaluating ELT textbooks and materials. ELT journal, 42(4), 237-246.

9. Ur, P. (1996). A Course in Language Teaching. Cambridge: Cambridge University Press.

10. Tomlinson, B. (2010). What do teachers think about EFL course books.Modern English Teacher, 19(4), 5-9.

11. Mukundan, J. (2007). 'Evaluation of English Language Textbooks: Some Important Issues for Consideration'. Journal of NELTA, 12(1\&2).

12. McGrath, I. (2002). Materials Evaluation and Design for Language Teaching Edinburgh Textbooks in Applied Linguistics. Applied Linguistics, 101, 57161.

13. Kirkgöz, Y. (2009). Evaluating the English textbooks for young learners of English at Turkish primary education. Procedia-Social and Behavioral Sciences, 1(1), 79-83.

14. Yasemin, K. (2009). Evaluating the English textbooks for young learners of English at Turkish primary education. Procedia-Social and Behavioral Sciences, 1(1), 79-83.

15. Angell, J., DuBravac, S., \&Gonglewski, M. (2008). Thinking Globally, Acting Locally: Selecting Textbooks for College-Level Language Programs. Foreign Language Annals, 41(3), 562-573.

16. Mukundan, J., \& Kalajahi, S. A. R. (2013). Evaluation of Malaysian English language teaching textbooks. International Journal of Education and Literacy Studies, 1(1), 38-46.

17. Mukundan, J., \& Roslim, N. (2009). Textbook Representation of Prepositions. English language teaching, 2(4), 13-24.

18. Ansary, H., \&Babaii, E. (2002). Universal characteristics of EFL/ESL textbooks: A step towards systematic textbook evaluation. The Internet TESL Journal, 8(2), $1-9$.

19. Akef, K., \&Moosavi, Z. (2014). Iranian EFL teachers' and students' textbook evaluation. The Iranian EFL Journal, $10(6), 1$.

\section{AUthors ProfiLe}

Muska Momand is a skilled instructor attached with the University of Balkh, Afghanistan. Currently, she's enrolled in a postgraduate course at Universiti Teknologi Malaysia to complete her Masters degree in TESL.

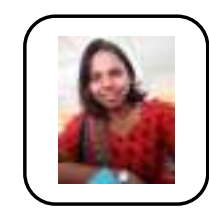

Ambiga Sugunabalan is a qualified primary school teacher working with the Ministry of Education Malaysia with a B.Ed. (TEYL) Hons. She also recently completed her postgraduate course in Master of Education (TESL) at Universiti Teknologi Malaysia.

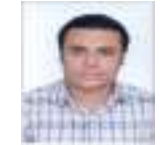

Said Ahmed Mustafa Ibrahim is an experienced ESL instructor from Alexandria, Egypt with a recent Master of Education in TESL, a TEFL Certificate from London Teacher Training College, a 2-year Post Graduate Diploma in TEFL and a B.Ed in English Literature and

Education.

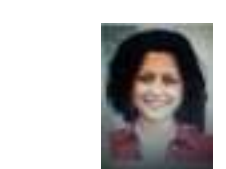

Sandaran, SC. (Ph.D), senior lecturer. Areas of interest: Critical Discourse Analysis, TESL, Service Learning, Engineering Texts. Language Academy, Faculty of Social Sciences and Humanities,UniversitiTeknologiraysia.Tel: +60167771364 E-mail: shanti@utm.my 